\title{
DAILY MEASUREMENT OF PITUITARY LH CONTENT DURING PREGNANCY IN THE RAT: DO CYCLIC CHANGES PERSIST?
}

\author{
NEENA B. SCHWARTZ AND WILLIAM L. TALLEY \\ Department of Physiology, University of Illinois College of Medicine, \\ Chicago, Illinois, U.S.A.
}

(Received 24th October 1966, revised 11th December 1966)

\begin{abstract}
Summary. Daily measurements of pituitary LH content during pregnancy in the rat, by the ovarian ascorbic acid depletion method, reveal no evidence of the regular changes manifested during the non-pregnant oestrous cycle. Instead, LH content rises from typical oestrous values on Day 1 to levels characteristic of cyclic pro-oestrus on Day 8. Pituitary LH content then exceeds pro-oestrous levels throughout the remainder of pregnancy until Day 21. Ovarian weight first decreases up to Day 10, then rises until the end of pregnancy. Ovarian histology reveals the presence of follicles of all sizes on each day, accompanied by increasing size of the corpora lutea of pregnancy. The significance of these observations and previous data in the literature concerning the pituitaryovarian axis during pregnancy are discussed from the point of view of the question of persistence of some manifestations of the oestrous cycle during pregnancy.
\end{abstract}

\section{INTRODUCTION}

In 1952 Zeiner published a study of the daily fluctuations in total gonadotrophic potency of rat pituitary glands during pregnancy which claimed to show evidence that the peak potency was reached on Days 6, 10, 16, 20 and 22 (counting the day spermatozoa were found as Day 1). Since some other evidence had also suggested occasional persistence of various measures of oestrous cycle changes during pregnancy (Evans \& Swezy, 1931; Nelson, 1929; Slonaker, 1925), Zeiner's study has led to the frequent assertion that an 'underlying' ovarian-pituitary cycle persists during pregnancy.

In the present study, using a specific measure of LH (Parlow, 1961), this issue is re-examined in the light of recent information on the true cyclic variation of pituitary LH content in the non-pregnant rat (Schwartz \& Bartosik, 1962; Schwartz, 1964), information which was not available at the time of Zeiner's study. In addition to daily assays of pituitary LH content, pituitary and ovarian weights were measured and ovarian histology was examined.

While this manuscript was in preparation, Greenwald (1966) published a study on pituitary FSH and LH content measured at 4-day intervals during pregnancy in the rat. Since it is impossible to assess the presence of a 4- or 5-day 
cycle from samples taken at 4-day intervals, Greenwald's study could not test the specific hypothesis of persistent cyclicity during pregnancy, although it contributes data of value to the general question of pituitary function in the pregnant rat.

\section{MATERIALS AND METHODS}

Virgin female rats (age 79 to 160 days) from Sprague-Dawley Inc. were mated with males of the same strain; the lst day of pregnancy was the day on which spermatozoa were seen in the vaginal smear and/or copulatory plugs were found. All rats were maintained under constant conditions (lights on from 05.00 to 19.00 hours). From two to five females were autopsied between 10.00 and 11.00 hours on each day of pregnancy (total 58). The anterior pituitary was separated from the posterior, weighed and quick frozen (Schwartz \& Bartosik, 1962). In most cases the pituitary from each rat was collected and assayed separately, but two pituitaries were generally pooled for assay in early pregnancy (to Day 8). Ovarian weight (single) was also measured, and in nineteen cases serial sections of the other ovary (plus oviduct) were made. In addition to pregnant donors, four pro-oestrous and four oestrous rats were autopsied and two pituitary pools apiece were collected for assay.

The four-point assay used for LH content in the pituitary is our modification (Schwartz, 1964; Schwartz \& Bartosik, 1962) of the ovarian ascorbic acid test (Parlow, 1961). NiH-LH-s5 was used as the standard in doses of 0.4 and 1.6 $\mu \mathrm{g} /$ recipient rat (calculated in terms of the potency of the S1 standard). The pituitary material was assayed in doses of $1 / 16$ and $1 / 4,1 / 32$ and $1 / 8$ or $1 / 64$ and $1 / 16$, depending on the potency. On six occasions an assay had to be rejected because of an inaccurate prediction of the potency, with resultant different slopes between standard and unknown (Bliss, 1956). The only assay data reported below (34 pools) were obtained using the proper doses of unknown with statistically valid assays $(2+2)$ (Bliss, 1956).

\section{RESULTS}

Pituitary LH content can be seen in Table 1. LH content in the control nonpregnant rats is higher than has been seen previously in this laboratory but the usual pro-oestrous to oestrous drop is present. Day 1 of pregnancy reveals heterogeneous contents, as has been observed before, on the morning of ovulation (Schwartz, 1964; Schwartz \& Bartosik, 1962; Schwartz \& Calderelli, 1965). From Day 1 to Day $8 \mathrm{LH}$ contents range from oestrous to pro-oestrous levels but do not exceed this. LH contents then rise higher, and, while there is some fluctuation from day to day or animal to animal, content stays above prooestrous values until Day 21 and no 4- or 5-day cycle is evident. On Day 21, and until parturition, LH contents appeared to fall closer toward pro-oestrous LH levels.

Pituitary weights remained unchanged during pregnancy, as assessed by the regression of weight on the day of pregnancy $\left(b=-0.027 \mathrm{mg} /\right.$ day; $\left.s_{b}= \pm 0.04\right)$. Average (wet) pituitary weight was $10.0 \mathrm{mg}$ and $\mathrm{LH}$ concentration $(\mu \mathrm{g} / \mathrm{mg})$ showed the same changes as did the content during pregnancy (Table 1). 
TABLE 1

PITUITARY LH CONTENT DURING PREGNANGY IN THE RAT

\begin{tabular}{|c|c|c|c|c|}
\hline \multirow{3}{*}{\begin{tabular}{l}
\multicolumn{1}{c}{ Day } \\
Control \\
Pro-oestrus
\end{tabular}} & \multicolumn{4}{|c|}{ Pituitary $L H$ content $(\mu g)$ and potency ( $95 \%$ conf. lim.) } \\
\hline & \multicolumn{2}{|c|}{ Individual pools } & \multicolumn{2}{|c|}{ Combined } \\
\hline & $\begin{array}{l}13 \cdot 5 \\
12 \cdot 6\end{array}$ & $\begin{array}{l}(6 \cdot 5-51 \cdot 7) \\
(6 \cdot 4-38 \cdot 2)\end{array}$ & $13 \cdot 0$ & $(9 \cdot 4-18 \cdot 0) \dagger$ \\
\hline $\begin{array}{l}\text { Control } \\
\text { Oestrus }\end{array}$ & $\begin{array}{l}7 \cdot 4 \\
8 \cdot 1\end{array}$ & $\begin{array}{l}(4 \cdot 2-13 \cdot 7) \\
(5 \cdot 4-12 \cdot 7)\end{array}$ & $7 \cdot 9$ & $(6 \cdot 7-9 \cdot 3) \dagger$ \\
\hline Preg-1 & $\begin{array}{l}9 \cdot 7 \\
2 \cdot 9\end{array}$ & $\begin{array}{l}(5 \cdot 4-20 \cdot 4) \\
(1 \cdot 1-5 \cdot 2)\end{array}$ & $5 \cdot 4$ & $(1 \cdot 6-18 \cdot 4)^{*}$ \\
\hline Preg-2 & $9 \cdot 1$ & $(6 \cdot 2-14 \cdot 3)$ & & \\
\hline Preg-3 & $5 \cdot 8$ & $(2 \cdot 9-11 \cdot 0)$ & & \\
\hline Preg-4 & $10 \cdot 0$ & $(6 \cdot 5-16 \cdot 9)$ & & \\
\hline Preg-5 & $8 \cdot 2$ & $(4 \cdot 7-12 \cdot 7)$ & & \\
\hline Preg-6 & $\begin{array}{l}12 \cdot 7 \\
13 \cdot 1\end{array}$ & $\begin{array}{l}(8 \cdot 2-19 \cdot 5) \\
(7 \cdot 8-22 \cdot 0)\end{array}$ & $12 \cdot 8$ & $(10 \cdot 5-15 \cdot 7) \dagger$ \\
\hline Preg-7 & $13 \cdot 5$ & $(9 \cdot 0-23 \cdot 3)$ & & \\
\hline Preg-8 & $12 \cdot 9$ & $(8 \cdot 7-21 \cdot 5)$ & & \\
\hline Preg-9 & $17 \cdot 5$ & $(11 \cdot 6-28 \cdot 2)$ & & \\
\hline Preg -10 & $15 \cdot 6$ & $(8 \cdot 5-25 \cdot 1)$ & & \\
\hline Preg-11 & $23 \cdot 2$ & $(17 \cdot 5-30 \cdot 4)$ & & \\
\hline Preg-12 & $37 \cdot 4$ & $(19 \cdot 9-84 \cdot 6)$ & & \\
\hline Preg-13 & $\begin{array}{l}30 \cdot 7 \\
20.5\end{array}$ & $\begin{array}{l}(19 \cdot 4-58 \cdot 6) \\
(11 \cdot 1-35 \cdot 1)\end{array}$ & $25 \cdot 3$ & $(20 \cdot 8-30 \cdot 6) \dagger$ \\
\hline Preg-14 & $\begin{array}{l}16 \cdot 1 \\
37 \cdot 0\end{array}$ & $\begin{array}{l}(11 \cdot 0-22 \cdot 3) \\
(23 \cdot 8 \cdot 62 \cdot 7)\end{array}$ & $24 \cdot 0$ & $(10 \cdot 3-56 \cdot 2)^{*}$ \\
\hline Preg-15 & $15 \cdot 1$ & $(9 \cdot 2-25 \cdot 9)$ & & \\
\hline Preg-16 & $17 \cdot 3$ & $(9 \cdot 3-28 \cdot 4)$ & & \\
\hline Preg-17 & $\begin{array}{l}32 \cdot 4 \\
19 \cdot 6\end{array}$ & $\begin{array}{l}(23 \cdot 1-47 \cdot 0) \\
(11 \cdot 2-31 \cdot 8)\end{array}$ & $27 \cdot 6$ & $(24 \cdot 0-31 \cdot 7) \ddagger$ \\
\hline Preg-18 & $\begin{array}{l}18 \cdot 5 \\
19 \cdot 8\end{array}$ & $\begin{array}{l}(11 \cdot 9-27 \cdot 3) \\
(11 \cdot 8-31 \cdot 2)\end{array}$ & $19 \cdot 0$ & $(16 \cdot 4-22 \cdot 1) \dagger$ \\
\hline Preg-19 & $27 \cdot 2$ & $(22 \cdot 2-33 \cdot 5)$ & & \\
\hline Preg-20 & 21.9 & $(16 \cdot 4-28 \cdot 8)$ & & \\
\hline Preg-21 & $\begin{array}{l}13 \cdot 2 \\
11 \cdot 0\end{array}$ & $\begin{array}{l}(7 \cdot 8-19 \cdot 8) \\
(2 \cdot 0-24 \cdot 9)\end{array}$ & $12 \cdot 9$ & $(10 \cdot 8-15 \cdot 5) \dagger$ \\
\hline Preg-22 & $21 \cdot 2$ & $(15 \cdot 6-30 \cdot 2)$ & & \\
\hline Preg-23 & $15 \cdot 0$ & $(11 \cdot 6-19 \cdot 4)$ & & \\
\hline
\end{tabular}

* Two pools heterogeneous $(P<0.0 \mathrm{I})$ (Bliss, 1956); confidence limits include variance between pools.

$\dagger$ Two pools homogeneous $(P>0 \cdot 25)$ (Bliss, 1956).

$\ddagger$ Two pools homogeneous $(0 \cdot 10>P>0 \cdot 05)$ (Bliss, 1956). 
Ovarian weights, on the other hand, fell from Day 1 to Day 10 and then rose from Day 12 until the end of pregnancy. The slope from Days 1 to 12 was -1.38 $\mathrm{mg} /$ day $\left(\mathrm{s}_{\mathrm{b}}= \pm 0.42 ; \mathrm{t}=3.26, \mathrm{df}=27, P<0.01\right)$ and average ovarian weight was $42.2 \mathrm{mg}$; the slope from Days 12 to 23 was $+1.98 \mathrm{mg} /$ day $\left(\mathrm{s}_{\mathrm{b}}= \pm 0.62\right.$; $\mathrm{t}=3.21$, df $=27, P<0.01)$ and average ovarian weight was $55.8 \mathrm{mg}$.

Serial sections of the ovaries and oviducts from the first 2 days of pregnancy revealed cleaving ova in the oviducts, and ovaries which resembled those from cyclic rats on the first 2 days after ovulation. On Days 4 and 5 large follicles resembling those found at pro-oestrus in cyclic animals were seen (Pl. 1, Fig. 1) and the corpora lutea from the most recent ovulation were prominent. Thereafter, ovarian histology at 2-day intervals revealed the gradual disappearance of all corpora lutea other than the last set, which became increasingly more prominent and the presence, in each ovary examined, of follicles of every size, including a small set of large ones (Pl. 1, Figs. 1 to 4) (see Greenwald, 1966). In every ovary examined, small 'luteinized' follicles were seen which inevitably contained an ovum (see section in Pl. 1, Fig. 4). In no case, from Day 4 on, were ova seen in the oviduct.

\section{DISCUSSION}

None of the variables examined in the present study-ovarian weight and histology, pituitary weight and LH content-showed evidence of cyclic changes of a 4- or 5-day period during pregnancy. Moreover, careful re-examination of the previously reported data purporting to demonstrate cyclicity during pregnancy in: (a) total pituitary gonadotrophin content (Zeiner, 1952), (b) spontaneous activity (Slonaker, 1925), (c) follicular growth and atresia (Evans \& Swezy, 1931), and (d) vaginal cornification and mating (Nelson, 1929) forces one to conclude that these reports provided little objective evidence that is convincing. Greenwald (1966) concurs in this evaluation.

Although evidence for the persistence of ovarian and pituitary cyclicity during pregnancy in the rat is weak, significant changes in ovarian and pituitary function do occur during this luteal phase. The initial drop in ovarian weight is probably due to the disappearance of old corpora lutea (Pl. 1, Figs. 1 to 4) (Evans \& Swezy, 1931); the subsequent rise in ovarian weight was due to the increase in size of the corpora lutea of pregnancy (Pl. 1, Figs. 1 to 4) (Weichart \& Schurgast, 1942). As for pituitary LH content, during the first days the values range from oestrous levels to pro-oestrous levels (Table 1). There is no drop or rise associated with secretion of the 'oestrogen surge' on Day 4, in spite of the necessity of the pituitary for this ovarian secretion (Zeilmaker, 1963). It is not known, however, which pituitary hormone(s) is responsible for stimulating secretion of this oestrogen (Schlough, Schuetz \& Meyer, 1965). Furthermore, there is no abrupt drop to oestrous levels of LH on Day 5 or 6 when the next release of the 'ovulatory surge' of $\mathrm{LH}$ might have been expected; this correlates with the failure to ovulate. Then on Days 9 to $12 \mathrm{LH}$ content rises above prooestrous values (Table 1). All of the preceding statements also describe the changes seen during pseudopregnancy in the rat (Schwartz \& Rothchild, 1964; van Rees \& De Groot, 1965). However, on about the 13th day of pseudopregnancy pituitary LH content falls to oestrous values (Schwartz \& Rothchild, 
PLATE 1

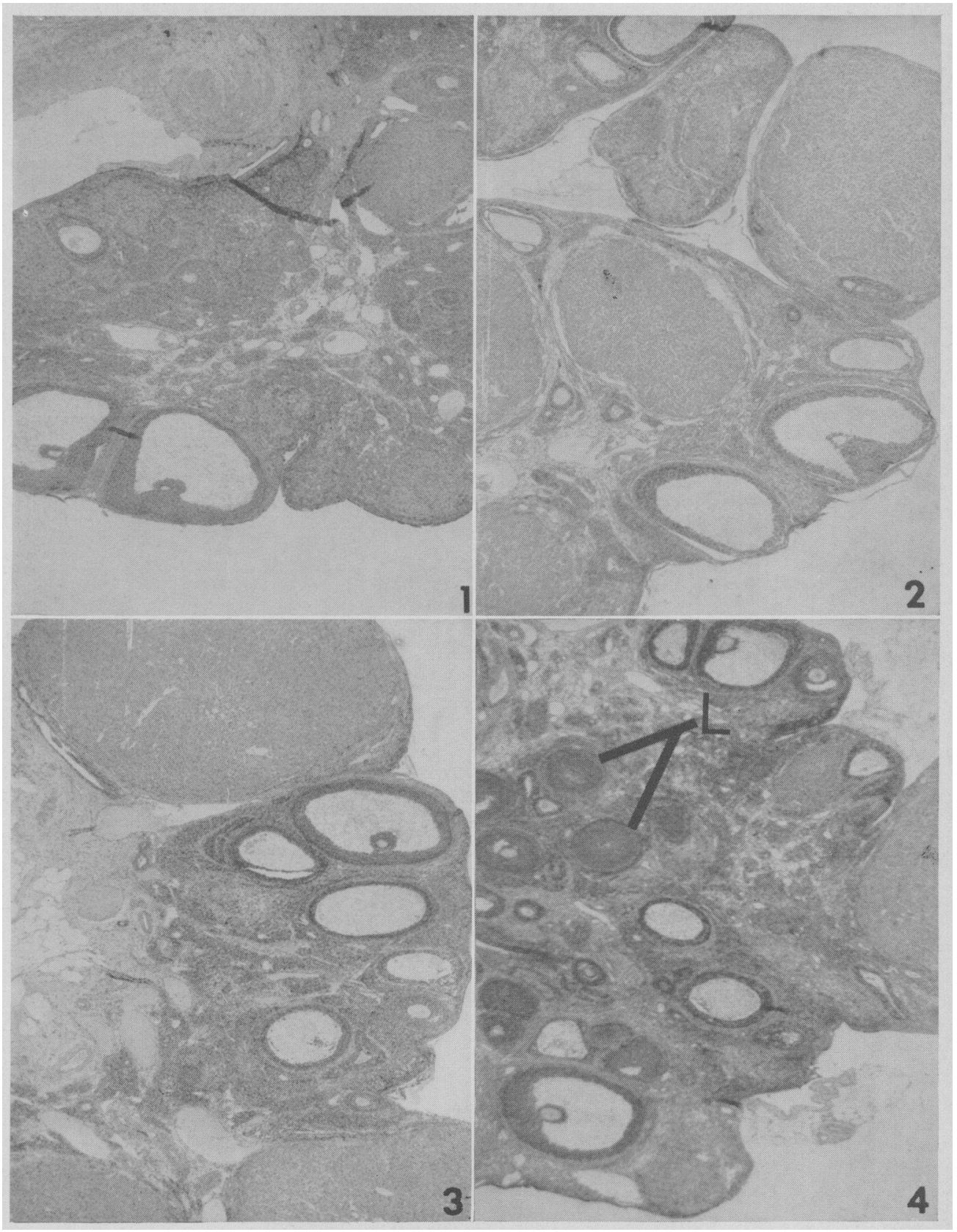

Fig. 1. Rat CF65 (Day 5). $\times 35$.

Fig. 2. Rat CF.52 (Day 9). $\times 35$.

Fis. 3. Rat CF22 (Day 13). $\times 35$.

Fic. 4. Rat CF10 (Day 18). × 35 .

$\mathrm{L}=$ 'Lutcinizing' follicles.

(Facing p. 42) 
1964; van Rees \& De Groot, 1965); this is in marked contrast to what happens in pregnancy (Table 1), when LH content never returns to oestrous levels. In Greenwald's recent study (1966), pituitary LH content, which was $4.6 \mu \mathrm{g}$ on Day 1 , rose only to levels of 14 to $17 \mu \mathrm{g}$ on Days $8,12,16$ and 20 , which is not as high as the overall levels seen in the present study after the 10th day. This is probably the result of his use of a three-point LH assay with $1 / 4$ pituitary equivalent as the only dose of 'unknown'; this dose was too high to fall within the range of our own dose-response curves and resulted in invalid assays which were discarded. With the three-point assay design, this lack of validity is undetectable and results in an underestimate of LH content.

The following sequence of events involving the ovarian-pituitary axis during pregnancy is suggested by the preceding observations, and others in the literature. Cervical stimulation induces the secretion of prolactin (luteotrophic for the rat) for about 7 days (Zeilmaker, 1965), apparently independently of mechanisms eliciting or inhibiting LH and FsH secretion (Rothchild, 1965; Everett \& Quinn, 1966). The secretion of luteotrophic hormone prolongs the life-span of the newest corpora lutea and progesterone secretion begins (Eto, Masuda, Shzuki \& Hosi, 1962). This progesterone suppresses the next behavioural oestrus and ovulation (Sawyer \& Kawakami, 1961; also see Rothchild, 1965, for a review of the literature) and is undoubtedly responsible for the rise in pituitary LH content during pseudopregnancy and in the first half of pregnancy (Hoffmann \& Schwartz, 1965b; Rothchild \& Schwartz, 1965; van Rees \& De Groot, 1965). If implantation occurs, luteotrophic hormone from the placenta assumes the role of maintaining the corpora lutea, and the pituitary becomes dispensible for corpora lutea maintenance and pregnancy, but not for follicular growth (Pencharz \& Long, 1933). However, during the time (Days 11 to 14 ) when the placenta is taking over luteotrophic function pituitary LH secretion may be necessary for corpus luteum maintenance (Alloiteau \& Bouhours, 1965). There may be a temporary drop in progesterone secretion around this time, which can result in termination of pregnancy, and/or oestrous activity and ovulation (Slonaker, 1925, 1934). During the latter half of pregnancy, the pituitary continues to store LH (Table 1) and FSH (Greenwald, 1966) but also releases enough of both hormones to cause follicular growth and some follicular luteinization (Pl. 1, Figs. 1 to 4) (Evans \& Swezy, 1931; Malven \& Sawyer, 1966; Greenwald, 1966); LH can be detected in the blood during pseudopregnancy and pregnancy (Anderson \& McShan, 1966) but an ovulatory surge is probably not released. Progesterone is probably partially responsible for the increased storage of LH in the latter half of pregnancy, but the steroid by itself was not able to maintain such high levels of LH when administered in daily doses of $10 \mathrm{mg}$ for 28 days (Rothchild \& Schwartz, 1965). Progesterone levels begin decreasing after the 15th day (Eto et al., 1962); this may account for the drop in LH content on Day 21 (Table 1) which could signify increased $\mathrm{LH}_{\mathrm{H}}$ release. This release might be responsible for maturation of the last crop of follicles, but is not responsible for the post-partum ovulation, since the LH release necessary for this does not occur until after parturition (Hoffmann \& Schwartz, 1965a; Kobayashi, Kobayashi, Tsuyuguchi \& Nagai, 1965).

The implication of the above sequence of hormonal secretions is that true 
cyclicity is not the common mode during pregnancy because progesterone prevents release of the ovulatory surge of $\mathbf{L H}$, which provides the terminal event in normal cycles, according to a recent model proposed to explain the rat oestrous cycle (Schwartz \& Hoffmann, 1967). Persistent oestrus does not, however, result from the blockade of ovulation during pregnancy, as it does in many other conditions, because progesterone also blocks overt vaginal cornification and the behavioural oestrus for the most part. Since progesterone does not block the secretion of the FSH and LH which is necessary for follicular growth and oestrogen secretion (Hoffmann \& Schwartz, 1965b; Rothchild, 1965; Schwartz \& Hoffmann, 1966), there is no theoretical reason why the progesterone might not permit some signs of oestrus occasionally while continuing to maintain the pregnancy (Nelson, 1929). What we should like to emphasize is that, even if occasional signs of ovarian and pituitary cyclicity were to be seen during pregnancy, this should still not be construed as evidence for 'inherent' persistence of cycles as though the timing of oestrous cycles is due to a 'built-in' 4- or 5-day rhythm. Rather, such timing is due to a complex series of feed-back relationships between the pituitary and ovary which are not eliminated during pregnancy (Schwartz \& Hoffmann, 1967), but are not usually manifested because of superimposition of a placenta-corpus luteum-pituitary axis.

\section{ACKNOWLEDGMENTS}

The authors wish gratefully to acknowledge the technical assistance of $\mathrm{Mr}$ Craig Holt and Mrs Deatra De Johnette, the generous supplies of NIH-LH from the Endocrinology Study Section and the use of environmentally controlled animal housing provided by the Aeromedical Laboratory under the direction of Dr John Marbarger. This study was supported in part by Grant HD-00440 from the National Institutes of Health.

\section{REFERENCES}

Allorteau, J. J. \& Bounours, J. (1965) Poursuite de la gestation chez la ratte hypophysectomisée recevant de l'hormone luteinisante. Réflexions sur les mécanismes successifs assurant le maintien fonctionnel du corps jaune gestatif. C. r. hebd. Séanc. Acad. Sci., Paris, 261, 4230.

Anderson, R. R. \& MCShan, W. H. (1966) Luteinizing hormone levels in pig, cow and rat blood plasma during the estrous cycle. Endocrinology, 78, 976.

Burss, C. I. (1956) Analysis of the biological assays in U.S.P. XV. Drug Stand. 24, 33.

Ero, T., Masuda, H., Shzuki, Y. \& Hosi, T. (1962) Progesterone and pregn-4-ene-20 $\alpha$-ol-3-one in rat ovarian venous blood at different stages in reproductive cycle. Fap. 7. Anim. Reprod. 8, 34.

Evans, H. M. \& Swezy, O. (1931) Ovogenesis and the normal follicular cycle in adult mammalia. Mem. Univ. Calif. 9, 119.

EveretT, J. W. \& QuinN, D. L. (1966) Differential hypothalamic mechanisms inciting ovulation and pseudopregnancy in the rat. Endocrinology, 78, 141.

Greenwald, G. S. (1966) Ovarian follicular development and pituitary FSH and LH content in the pregnant rat. Endocrinology, 79, 572.

Hoffmann, J. C. \& Schwartz, N. B. (1965a) Timing of post-partum ovulation in the rat. Endocrinology, 76,620 .

Hoffmann, J. C. \& Schwartz, N. B. (1965b) Timing of ovulation following progesterone withdrawal in the rat. Endocrinology, 76, 626.

Kobayashi, T., Kobayashi, T., Tsuyuguchi, M. \& Nagai, N. (1965) Fluctuations in FSH and LH content of the anterior pituitary of the castrated adult female and puerperal rat. Endocr. jap. 12, 289.

Malven, P. V. \& SAwYer, C. H. (1966) Formation of new corpora lutea in mature hypophysectomized rats. Endocrinology, 78, 1259.

Nexson, W. O. (1929) Oestrus during pregnancy. Science, N.Y. 70, 453. 
PARlow, A. F. (1961) Human pituitary gonadotropins, p. 300. Ed. A. Albert. Charles C. Thomas, Springfield, Illinois.

Pencharz, R. I. \& Long, J. A. (1933) Hypophysectomy in the pregnant rat. Am. F. Anat. 53, 117.

RotнCHILD, I. (1965) Interrelations between progesterone and the ovary, pituitary, and central nervous system in the control of ovulation and the regulation of progesterone secretion. Vitams Horm. 23, 209.

Rothchild, I. \& Schwartz, N. B. (1965) The corpus luteum-hypophysis relationship. The effects of progesterone and oestrogen on the secretion of luteotrophin and luteinizing hormone in the rat. Acta endocr., Copenh. 49, 120.

SAWYER, C. H. \& KAWAKAMI, M. (1961) Interactions between the central nervous system and hormones infuencing ovulation. In: Control of Ovulation, p. 79. Ed. C. A. Villee. Pergamon Press, London.

Schlough, J. S., Schuetz, A. W. \& Meyer, R. K. (1965) Induction of implantation in the hypophysectomized rat with gonadotrophins. Proc. Soc. exp. Biol. Med. 120, 458.

Schwartz, N. B. (1964) Acute effects of ovariectomy on pituitary LH, uterine weight, and vaginal cornification. Am. J. Physiol. 207, 1251.

Schwartz, N. B. \& BARTosiK, D. (1962) Changes in pituitary LH content during the rat estrous cycle. Endocrinology, 71, 756.

Schwartz, N. B. \& Galderelli, D. (1965) Plasma LH in cyclic female rats. Proc. Soc. exp. Biol. Med. $119,16$.

Schwartz, N. B. \& HoffmanN, J. C. (1967) A model for the control of the mammalian reproductive cycle. Proc. 2 nd int. Congr. Hormonal Steroids, I.C.S. No. 132, p. 997.

Schwartz, N. B. \& Rothchild, I. (1964) Changes in pituitary LH concentration during pseudopregnancy in the rat. Proc. Soc. exp. Biol. Med. 116, 107.

SLONAKER, J. R. (1925) The effect of copulation, pregnancy, pseudopregnancy and lactation on the voluntary activity and food consumption of the albino rat. Am. F. Physiol. 71, 362.

Slonaker, J. R. (1934) Superfetation in the albino rat. Am. F. Physiol. 108, 322.

VAN REeS, G. P. \& DE GROOT, C. A. (1965) Secretion of FSH and LH in the pseudopregnant rat. Acta endocr., Copenh. 49, 370.

Werghart, C. K. \& Schurgast, N. W. (1942) Variations in size of corpora lutea in the albino rat under normal and experimental conditions. Anat. Rec. 83, 321.

Zeilmaker, G. H. (1963) Experimental studies on the effects of ovariectomy and hypophysectomy on blastocyst implantation in the rat. Acta endocr., Copenh. 44, 355.

Zeilmaker, G. H. (1965) Normal and delayed pseudopregnancy in the rat. Acta endocr., Copenh. 49, 558. ZeINER, F. N. (1952) Pituitary gonadotropic fluctuation during pregnancy in the rat. Anat. Rec. 113, 255. 